dr hab. inż. Piotr Boguś

Instytut Pojazdów Szynowych ,TABOR”

Gdański Uniwersytet Medyczny

\title{
Wielorozdzielcza analiza falkowa $w$ diagnostyce silnika agregatu głównego lokomotywy spalinowej
}

\begin{abstract}
Artykut przedstawia możliwości zastosowania falkowej analizy wielorozdzielczej do diagnostyki silnika Diesla lokomotywy spalinowej. Analiza bazuje na sygnałach wibroakustycznych pozyskanych z silnika spalinowego przed i po generalnym remoncie lokomotywy i silnika. Istota analizy wielorozdzielczej jest rozłożenie sygnału na sktadowe aproksymacyjne, które reprezentuja różne poziomu szczegółowości sygnału. Badania pokazały wyraźne zróżnicowanie wykresów czasowo-częstotliwościowych wspótczynników transformaty falkowej. W celu diagnostycznym należy jednak oprzeć się nie tyle na analizie skalogramów i obrazów czasowo-przestrzennego rozkładu współczynników transformat falkowych, ale raczej na wyborze parametrów istotnych diagnostycznie nadajacych się do szybkiej analizy on-line. Do tego celu lepiej nadaje się wielorozdzielcza dekompozycja sygnału, która pozwala na analizę cech składowych na różnych poziomach szczególowości. (Artykul powstal w ramach projektu badawczego $\mathrm{Nr}$ 5406/B/T02/2011/40 pt. „Zastosowanie wybranych metod analizy sygnałów wibroakustycznych oraz technologii GPS dla monitorowania oraz oceny pozycji $i$ stanu pojazdu szynowego $w$ celu zwiększania bezpieczeństwa ruchu oraz lepszego zarządzania taborem kolejowym")
\end{abstract}

\section{Wstęp}

Transport kolejowy niewątpliwie zaczął nabierać dużego znaczenia w dzisiejszym świecie, a to głownie ze względu na jego zalety ekonomiczne i ekologiczne. Stąd też dla zapewnienia nowych wymagań typowych dla nowoczesnego środka transportu, dzisiejsza kolej potrzebuje nowych i innowacyjnych systemów dla usprawnienia bezpieczeństwa jazdy, komfortu oraz niezawodności.

To co jest szczególnie ważne i interesujące to wykrywanie krytycznych incydentów podczas ruchu pojazdu szynowego, które prowadzą lub mogą prowadzić do uszkodzenia, awarii, wypadku lub innej ryzykownej sytuacji. Może to być kolizja dwóch pojazdów, kolizja z przeszkodą lub wykolejenie się, które prowadzi do śmierci, kalectwa lub uszkodzeń ciała zranienia pasażerów, zniszczenia ładunku lub zewnętrznego środowiska naturalnego. Informacja o potencjalnych incydentach będzie określana na podstawie znajomości stanu pojazdu szynowego oraz danych diagnostycznych na temat silnika i innych urządzeń pojazdu [11, 16, 19].

W tym zakresie istotną role odgrywają diagnostyczne systemy pokładowe. Tego typu systemy, znane jako systemy OBD (ang. on-board diagnostic systems), są już powszechnie używane w samochodach osobowych [17]. Systemy te powszechne w dzisiejszych systemach samochodowych, nie znalazły dotąd powszechnego zastosowania w pojazdach szynowych. Tym nie mnie, należy się spodziewać, że pojawią się one również w ruchu kolejowym, szczególnie na lokomotywach spalinowych. Oczywiście nie będą one identyczne $\mathrm{z}$ tymi stosowanymi $\mathrm{w}$ samochodach, ale niewątpliwie jednym $\mathrm{z}$ ich elementów będą systemy analizujace sygnały wibroakustyczne w celu diagnostyki oraz wykrywania i rejestracji sytuacji krytycznych podczas ruchu pojazdu.

W zakresie analizy zanieczyszczeń dla samochodów osobowych pojawiły się już od dawna normy Euro, które nakładają na silniki samochodowe wymagania odnośnie emisji spalin. Realizowane są one poprzez wprowadzenie systemu urządzeń OBD, które definiuja ścisłe rodzaj urządzeń i procedur podczas oceny stanu silnika i pojazdu. Jak do tej pory brak jest podobnych rozwiązań dla lokomotyw spalinowych, choć jest tutaj kilka regulacji np. Cart UIC 623 1-2-3 w Europie. Niewattpliwie jednak najbliższe lata przyniosą zaostrzenie norm na emisje spalin I niewatpliwie dojdzie do przeniesienia tych norm na ciężkie silniki Diesla lokomotyw spalinowych.

W typowym urządzeniu rejestrującym ORD (ang. On-Board Recording Devices), które docelowo powinno zostać wprowadzone dla pojazdów szynowych, stan pojazdu jest określany na bazie sygnałów pozyskiwanych z urządzeń takich jak akcelerometry, żyro- 
skopy MEMS (ang. Micro Electro-Mechanical Systems) oraz odbiorniki GPS (ang. Global Positioning System). W praktyce każde urządzenie ORD jest więc wyposażone w odpowiednie akcelerometry. Stąd też wykorzystanie sygnałów wibroakustycznych dla celów diagnostycznych jest tak popularne i często stosowane. Wówczas po zarejestrowaniu określonego diagnostycznego sygnału wibroakustycznego trzeba dokonać jego analizy i na tym etapie stosuje się bardzo szeroki zakres metod przetwarzania sygnałów. Obok klasycznych metod obróbki sygnałów stosuje się wiele wyrafinowanych metod obliczeniowych, w tym analizę falkową oraz metody bazujące na sztucznej inteligencji.

Jak do tej pory eksperymenty w zakresie monitorowania uszkodzeń i zaburzeń pracy silnika na bazie sygnałów wibroakustycznych zostały przeprowadzone z wykorzystaniem wielu metod analizy sygnałów, w tym obliczanie globalnych statystycznych parametrów takich jak średnia, mediana, odchylenie standardowe itp., analiza nieliniowa z wykorzystaniem metod teorii chaosu deterministycznego, analiza krótkoczasowa, metodę maszyn wektorów wspierających SVM (ang. Support Vector Machines) [2, 3, 4, 5, 6, 7, 8, 9, 10]. Z praktycznego punktu wodzenia chodzi o znalezienie takich parametrów, które mogą być wprost zastosowane do diagnostyki on-line.

\section{Wielorozdzielcza analiza falkowa}

Falki (ang. wavelets) $[13,14]$ to funkcje matematycznymi tworzące bazę ortogonalną w zbiorze funkcji $\mathbf{L}^{2}$ (całkowalnych z kwadratem). Angielska nazwa „wavelet”, którą przetłumaczono na język polski jako „falka”, definiuje ją jako funkcję falująca, czyli taką, dla której całka od $-\infty$ do $+\infty$ była równa zero. Dodatkowo falki są zawsze zlokalizowane w określonym miejscu (w czasie lub przestrzeni) i powinny być funkcjami ciagłymi i różniczkowalnymi. Od falki żądamy w efekcie by była różniczkowalna w sposób ciagły i miała zwarty nośnik (była różna od zera dla skończonego przedziału). Pierwsze zaproponowane falki miały tę wadę, że były różniczkowalne w sposób ciagły, ale nie miały zwartego nośnika lub na odwrót. Pierwsza nietrywialna falkę o zwartym nośniku i różniczkowalną w sposób ciągły zaproponowała Ingrid Daubechies.

Użycie falek sprowadza się zastosowania wyjściowej falki bazowej (tzw. falki matki) w postaci $\psi((\mathrm{x}-$ b)/a). Dokonując jej przesuwanie i skalowanie otrzymujemy zbiór falek tworzących bazę ortogonalna w przestrzeni funkcyjnej, gdzie b to liczba rzeczywista opisująca przesunięcie, natomiast a to liczba rzeczywista dodatnia opisująca skalę. Porównując falki $\mathrm{z}$ Fourierowskimi funkcjami bazowymi (sinusem lub cosinusem), należy podkreślić, że falki powstają przez skalowanie (rozciaganie lub ściskanie) funkcji matki oraz przez jej przesunięcie, podczas gdy bazowe funkcje Fourierowskie są jedynie skalowane. W analizie Fourierowskiej funkcje sinus i cosinus mają lokalizację w częstotliwości, ale brak takiej lokalizacji w czasie lub przestrzeni. Powoduje to, że mała lokalna zmiana w sygnale w po stronie częstotliwości objawia się wprawdzie $\mathrm{w}$ dziedzinie czasu lub przestrzeni, ale nie wiemy gdzie. Falki natomiast sa zlokalizowane zarówno w czasie (poprzez przesunięcia) jak i w częstotliwości (poprzez skalowanie).

Falki zostały rozwinięte niezależnie $\mathrm{w}$ takich dyscyplinach jak matematyka, fizyka kwantowa, elektronika i geologia sejsmiczna i znalazły zastosowanie $\mathrm{w}$ kompresji obrazów, analizie turbulencji, badaniach nad widzeniem i rozpoznawaniem obrazów, radarach i predykcji trzęsień ziemi. Falki znalazły również zastosowanie w zakresie analizy szerokiej klasy sygnałów pozyskiwanych $\mathrm{w}$ mechanice dla celów diagnostycznych. Bazując na sygnałach wibroakustycznych falki były stosowane w diagnostyce silników spalinowych do wykrywania wypadania zapłonu, diagnostyki cylindrów, detekcji i diagnostyki uszkodzeń elementów obrotowych, detekcji uszkodzeń zaworów itp. [1, 12, $15,18,20]$.

W ciagłej transformacie falkowej CWT (ang. continuous wavelet transoformation) $[13,14]$ podstawową role odgrywa bazowa falka matka $\psi(x)$. Bazę ortonormalna jest utworzona przez przesuwanie i skalowanie falki matki

$$
\frac{1}{\sqrt{\mathrm{a}}} \psi\left(\frac{\mathrm{x}-\mathrm{b}}{\mathrm{a}}\right)=\psi_{\mathrm{a}, \mathrm{b}}(\mathrm{x})
$$

gdzie $\mathrm{b}$ to przesunięcie, natomiast a skala. Wówczas dowolna funkcji $\mathrm{f}(\mathrm{x}) \in \mathbf{L}^{2}$ może być rozłożona

$$
\mathrm{W}_{\mathrm{f}}(\mathrm{a}, \mathrm{b})=\left\langle\mathrm{f}, \psi_{\mathrm{ab}}\right\rangle=\int_{-\infty}^{+\infty} \mathrm{f}(\mathrm{x}) \psi_{\mathrm{ab}}(\mathrm{x}) \mathrm{dx}
$$

gdzie $\mathrm{W}_{\mathrm{f}}(\mathrm{a}, \mathrm{b})$ to CWT funkcji $\mathrm{f}(\mathrm{x}), \mathrm{a}\left\langle\mathrm{f}, \psi_{\mathrm{ab}}\right\rangle$ to iloczyn skalarny $f(x)$ i $\psi_{a, b}(x)$. Transformata falkowa $\mathrm{W}_{\mathrm{f}}(\mathrm{a}, \mathrm{b})$ jest funkcją dwóch zmiennych zależną od a i b. w ciagłej transformacie falkowej CWT. Tak więc ciagła transformata falkowa $\mathrm{W}_{\mathrm{f}}(\mathrm{a}, \mathrm{b})$ jednowymiarowej funkcji $\mathrm{f}(\mathrm{x})$, jest funkcją dwuwymiarową.

W literaturze można znaleźć wiele bazowych układów falek. Mają on różne postacie, czasem niedające się zapisać analitycznie. Pierwsze funkcje używane obecnie jako falki pojawiły się $\mathrm{w}$ dodatku do pracy doktorskiej Haara (1909) i są obecnie znane, jako funkcje Haara. Pierwsze nie trywialne falki wprowadził Meyer. Jego falki były ciagłe, ale nie miały zwartego nośnika. Dopiero Ingrid Daubechies zaproponowała pierwszy zbiór falek ortonormalnych, mających zwarty nośnik i różniczkowalnych w sposób ciagły.

CWT są wprawdzie stale używane, ale niewatpliwie dokonywania jej dla wszystkich możliwych przesunięć i skal produkuje bardzo dużo danych. Stąd też dużo częściej w praktyce stosuje się dyskretną trans- 
formate falkową DWT (ang. discrete wavelet transform) $[13,14]$. W DFT odpowiedni sygnał przekształcany jest do dyskretnej skali i dyskretnych przesunięć. Daje to znaczną redukcję ilości danych Dyskretna transformata falkowa pozwala reprezentować funkcje $\mathrm{f}(\mathrm{x})$ w następujący sposób

$$
f(x)=\sum_{j, k} d_{j k} \psi_{j k}(x)
$$

gdzie

$$
\psi_{\mathrm{jk}}(\mathrm{x})=2^{\frac{\mathrm{j}}{2}} \psi\left(2^{\mathrm{j}} \mathrm{x}-\mathrm{k}\right)
$$

Funkcje bazowe są tworzone na podstawie macierzystej falki $\psi(\mathrm{x})$ poprzez $\mathrm{z}$ rozszerzenie $\mathrm{j}$ oraz przesunięciem $\mathrm{k}$. W praktyce używa się tzw. binarną dyskretną transformatę falkową, w której odpowiednie współczynniki są reprezentowane jako potęgi 2 (skala $a_{k}=2^{-k}$, przesunięcie $b_{k}=2^{-k}$ ).

Zastosowanie transformaty DWT daje możliwość przeprowadzenia tzw. analizy wielorozdzielczej MRA (ang. multiresolution analysis), w której sygnał oryginalny jest poddawany dekompozycji (rozkładany) na człon aproksymacyjny niskoczęstotliwościowy oraz człon aproksymacyjny wysokoczęstotliwościowy [13, 14]. Ściśle analiza wielorozdzielcza przedstawia sygnał jako sumę tzw. funkcji skalujących oraz bazowych funkcji falkowych. Operację ta można powtarzać i na każdym poziomie dokonać następnej dekompozycji. Przykład takiego rozkładu na poziomie 5 (zastosowanym praktycznie w pracy) pokazuje rys. 1.

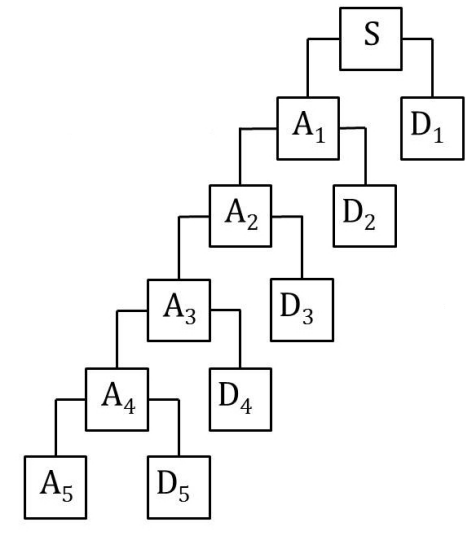

Rys. 1. Przykładowa struktura drzewa dla 5 poziomowej wielorozdzielczej dekompozycji

W tym opisie człony typu $A_{i}$ reprezentują niskoczęstotliwościowe składowe odpowiadające dekompozycji z dużą skalą, a człony $\mathrm{D}_{\mathrm{j}}$ człony wysokoczęstotliwościowe odpowiadające dekompozycji z mała skalą. Dekompozycja wielorozdzielcza działa w sposób następujący

- załóżmy, że sygnał $\mathrm{S}$ ma $\mathrm{N}$ próbek i jego zakres częstotliwościowy wynosi $0 \div \mathrm{f}_{\mathrm{g}}$, gdzie $\mathrm{f}_{\mathrm{g}}$ to częstotliwość graniczna, wówczas
- na poziomie 1 rozkładu: $\mathrm{A}_{1}$ jest członem niskoczęstotliwościowym, który ma $\mathrm{N} / 2$ próbek i obejmuje pasmo częstotliwości $0 \div \mathrm{f}_{\mathrm{g}} / 2, \mathrm{D}_{1}$ jest członem wysokoczęstotliwościowym, który ma $\mathrm{N} / 2$ próbek i obejmuje pasmo $\mathrm{f}_{\mathrm{g}} / 2 \div \mathrm{f}_{\mathrm{g}}$,

- na poziomie 2 rozkładu: $A_{2}$ to człon niskoczęstotliwościowy ( $\mathrm{N} / 4$ próbek, pasmo $\left.0 \div \mathrm{f}_{\mathrm{g}} / 4\right), \mathrm{D}_{1}$ to człon wysokoczęstotliwościowy (N/4 próbek, pasmo $\left.f_{g} / 4 \div f_{g} / 2\right)$,

- itd.

- na poziomie 5 rozkładu: $\mathrm{A}_{2}$ to człon niskoczęstotliwościowy (N/32 próbek, pasmo $\left.0 \div \mathrm{f}_{\mathrm{g}} / 32\right)$, $\mathrm{D}_{1}$ to człon wysokoczęstotliwościowy (N/32 próbek, pasmo $\mathrm{f}_{\mathrm{g}} / 32 \div \mathrm{f}_{\mathrm{g}} / 16$ ).

Schemat analizy wielorozdzielczej z falkami może być reprezentowany jako zespół pasmowoprzepustowych filtrów cyfrowych. W praktyce obliczanie współczynników rozkładu, ze względu na duża złożoność oraz czasochłonność, jest realizowana właśnie przy pomocy specjalnych filtrów cyfrowych. Po jednokrotnej dekompozycji ilość próbek, które reprezentują sygnał ulega podwojeniu. Z tego powodu, stosuje się tzw. decymację (ang. downsampling), w której za filtrem dochodzi do usunięcia co drugiej próbki.

\section{Metodyka pomiarowa}

Badania zostały przeprowadzone na lokomotywie spalinowej serii ST44. Ma ona sześć zestawów kołowych, umieszczonych na dwóch wózkach i wszystkie zestawy kołowe są napędowe, a każdy z nich jest napędzany oddzielnym elektrycznym silnikiem trakcyjnym. Zadaniem przekładni elektrycznej jest przeniesienie momentu obrotowego od spalinowego silnika wysokoprężnego na zestawy kołowe lokomotywy. Przedmiotem badań był silnik spalinowy 14D40 nr 8849. Pomiary wykonano pod obciążeniem (na oporniku wodnym) dla odpowiednio dostosowanych mocy w wyznaczonych punktach pomiarowych. Badania oparto na porównaniu sygnałów wibroakustycznych zarejestrowanych z silnika przed i po remoncie. Pomiary przyspieszeń dla lokomotywy ST44-2045 były przeprowadzone przed i po naprawie rewizyjnej wykonanej w stacji diagnostycznej w Zamościu. Okresowy remont polegał na pełnym serwisie części układów oraz na wymianie elementów uszkodzonych lub zużytych $[9,10]$.

Pomiary przyspieszeń przed remontem wykonano przy pomocy czujników przyspieszeń serii EGCS firmy Entran Devices o zakresie $\pm 5 \mathrm{~g}$, przy użyciu karty analogowo-cyfrowej PCL-818HD firmy ADVANTECH, przy częstotliwości próbkowania $1004,0161 \mathrm{~Hz} /$ kanał. Po naprawie pomiarów dokonano przy użyciu wyżej wymienionych czujników EGCS oraz dodatkowo przy użyciu czujników PCB PIEZOELECTRONICS model 393B04 [9, 10]. 


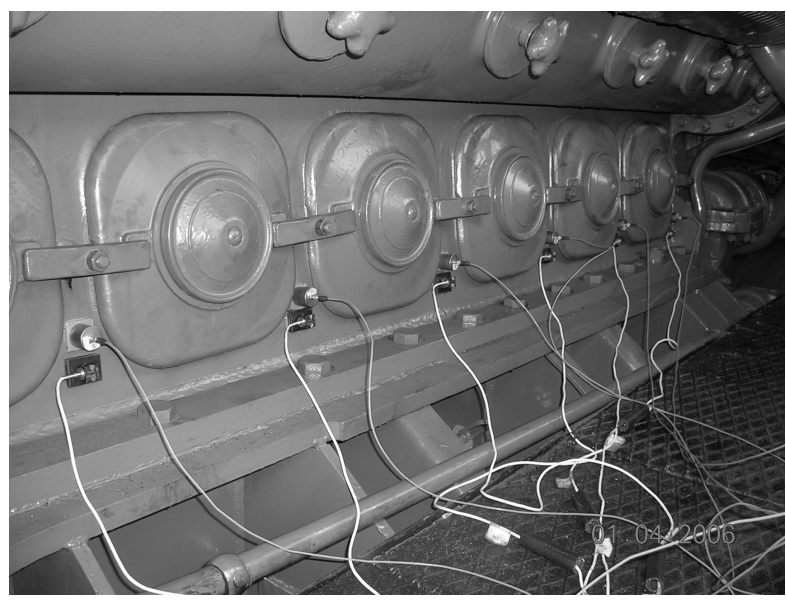

Rys. 2. Przykład mocowania czujników na korpusie silnika lokomotywy

Czujniki mocowano na korpusie silnika w miejscach odpowiadających łożyskowaniu wału korbowego silnika (patrz rys. 2). Każdy punkt pomiarowy rejestrował przyspieszenia $\mathrm{w}$ kierunku pionowym oraz poziomym poprzecznym $[9,10]$. Każdy pomiar przed i po naprawie był przeprowadzony dla wybranych nastaw mocy oraz prędkości obrotowej silnika. Analiza tego typu sygnałów była już prowadzana przy zastosowaniu metod nieliniowych, metody wektorów wspierających SVN oraz metod krótkoczasowych [2, $3,4,5,6,7,8,9,10]$. Wyniki badan metodami krótkoczasowymi potrafily rozróżnić pomiędzy stanami silnika zużytego i pracującego normalnie, co dało impuls do przeprowadzenia badań przy użyciu falek.

Wszystkie obliczenia zostały wykonane przy użyciu programu MATLAB. Badaniom poddano sygnały bez obróbki wstępnej w postaci otrzymanej z urządzenia rejestrującego. Analiza tych sygnałów wibroakustycznych przed i po remoncie została dokonana na bazie wielorozdzielczej dekompozycji na poziome 5 . Przykładowe sygnały wibroakustyczne oraz wykresy falkowe są pokazane na rys. 3 i 4.

A)

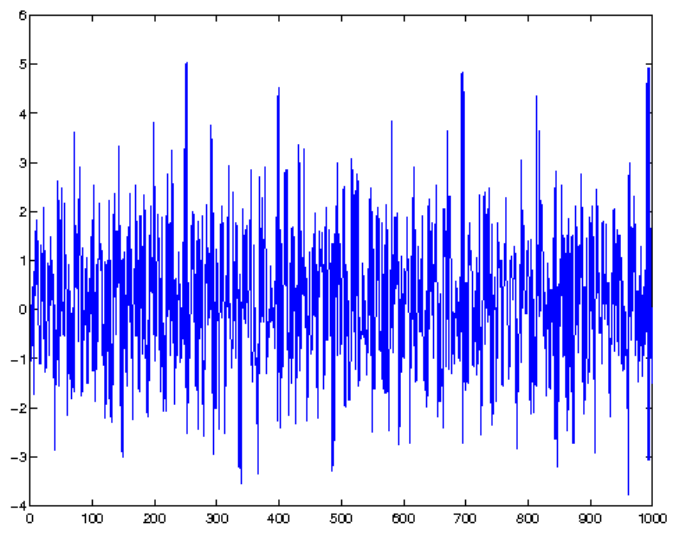

B)

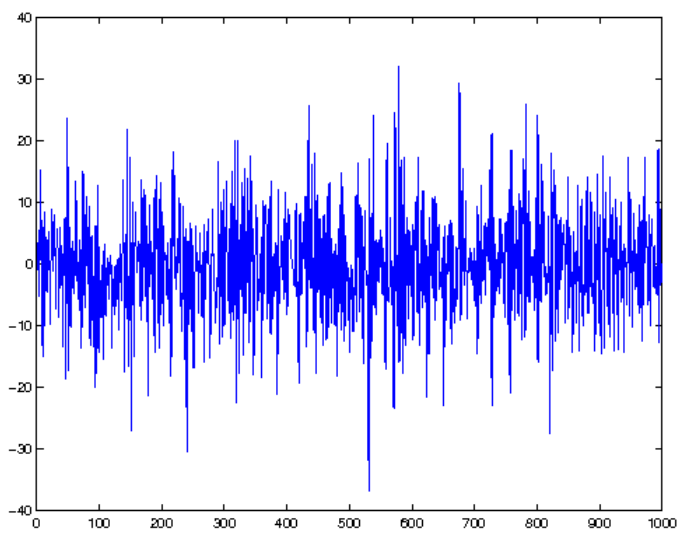

Rys. 3. Przykładowe sygnały wibroakustyczne pozyskane w kierunku poziomym prostopadłym przed naprawą (A) i po naprawie (B)

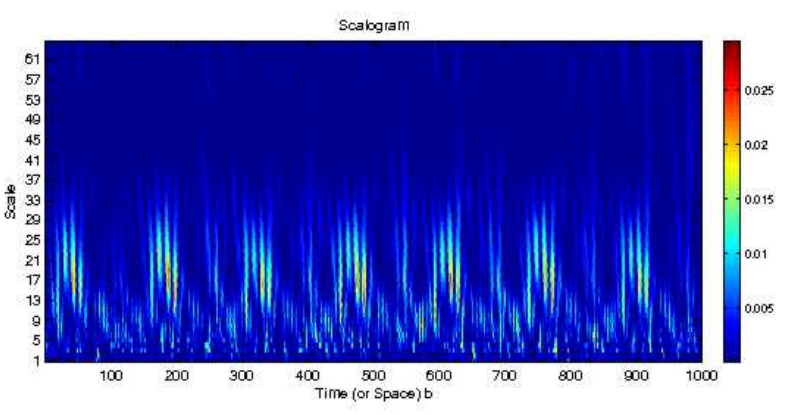

przed

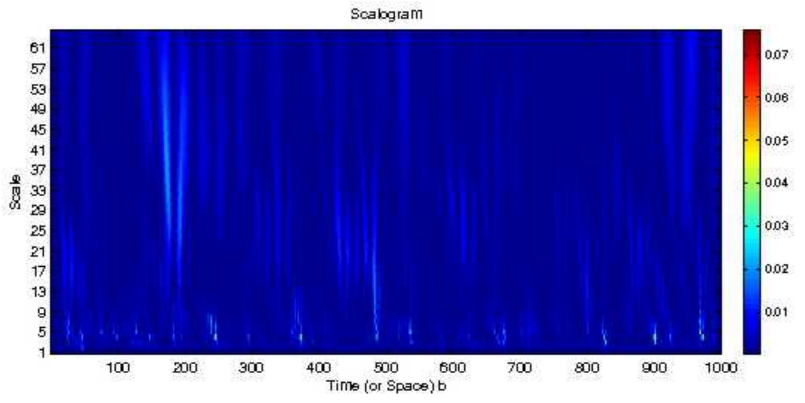

po

Rys. 4. Przykładowy wynik CWT dla falki db3 dla sygnału wibroakustycznego (kierunek poziomy prostopadły)

\section{Rezultaty}

Badania wstępne objęły wykorzystanie różnych rodzajów falek (Daubechies, Haar, Morlet) oraz danej falki (Daubechies) dla różnych poziomów skalowania. Pokazały one na dużą zmienność danych wynikowych w postaci zarówno obrazów, jak i odpowiednich współczynników. Wskazuje to na, że przed przystąpieniem do badań diagnostycznych z użyciem falek, należy przetestować różne ich rodzaje.

A gdy już zdecydujemy się do wykorzystania danej falki w zadaniu diagnostycznym, nie wolno zmieniać rodzaju używanej falki w trakcie badań. Ostatecznie do badań wybrano falkę Daubechies trzeciego rzędu (db3).

Badani objęły najpierw zastosowanie ciagłej transformaty falkowej do porównania sygnałów przed i po naprawie. Wizualna ocena wykresów czasowo- 

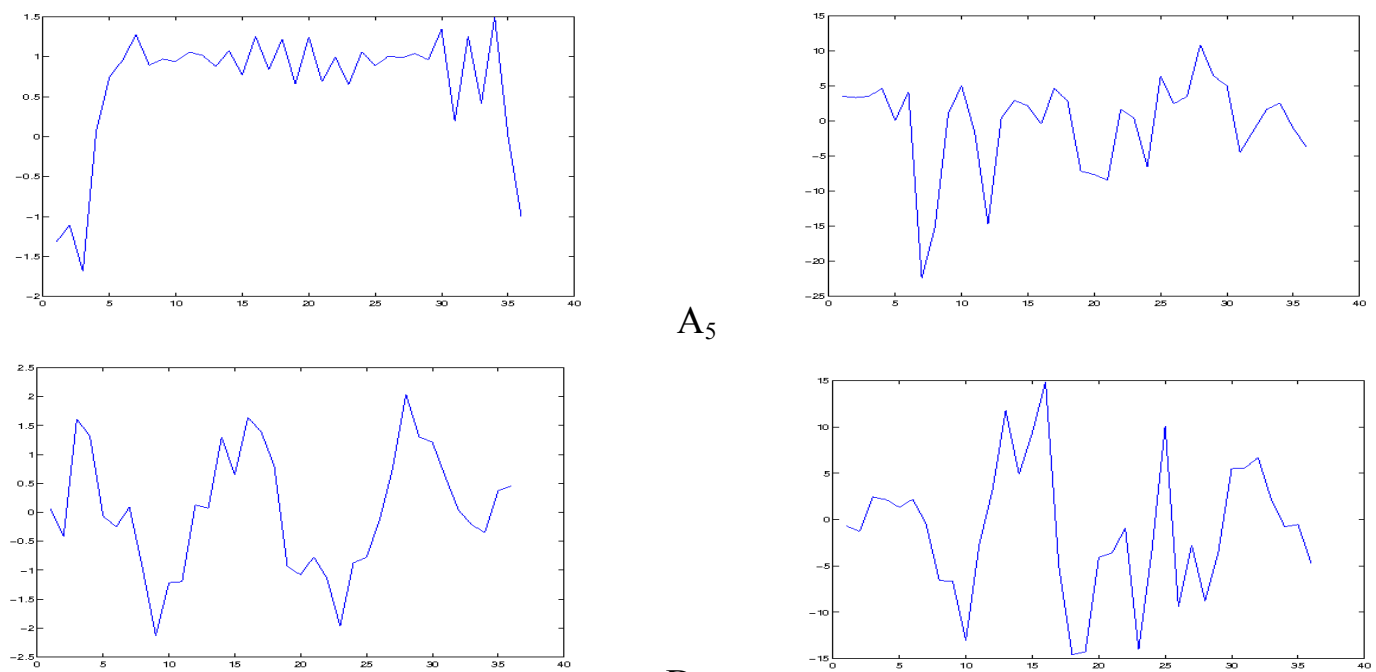

$\mathrm{A}_{5}$
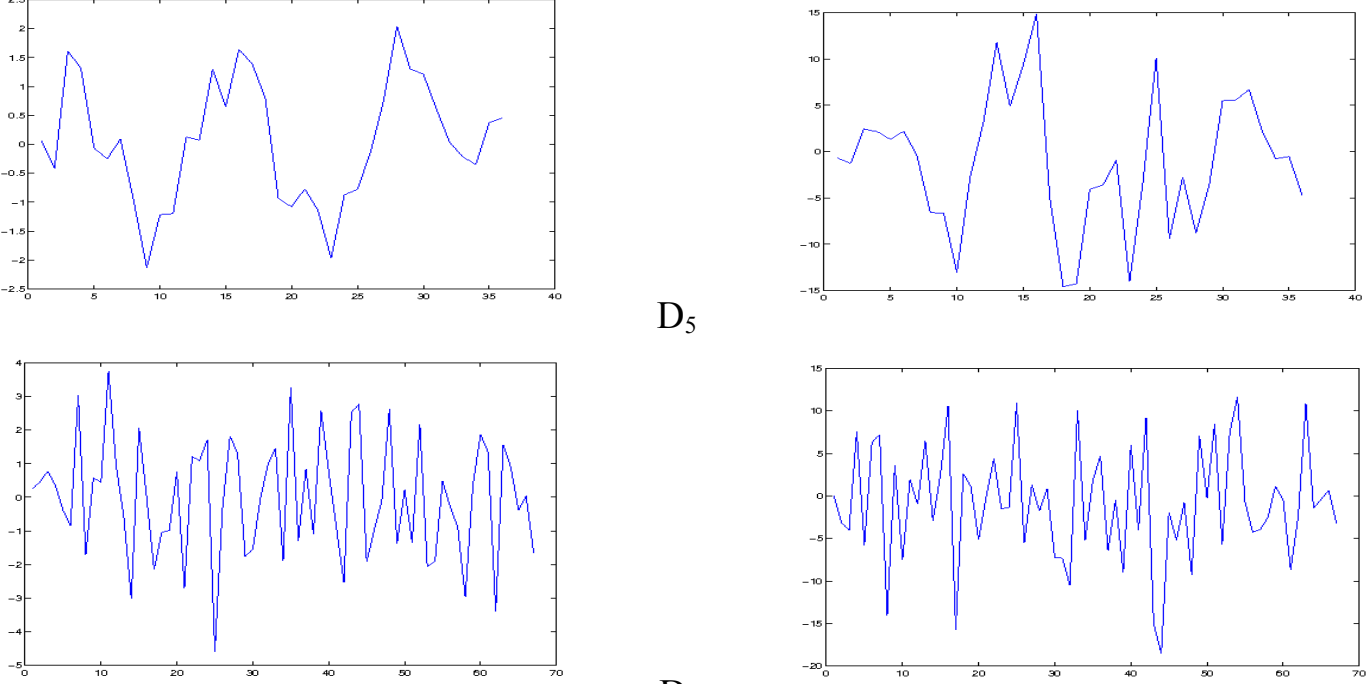

$\mathrm{D}_{4}$
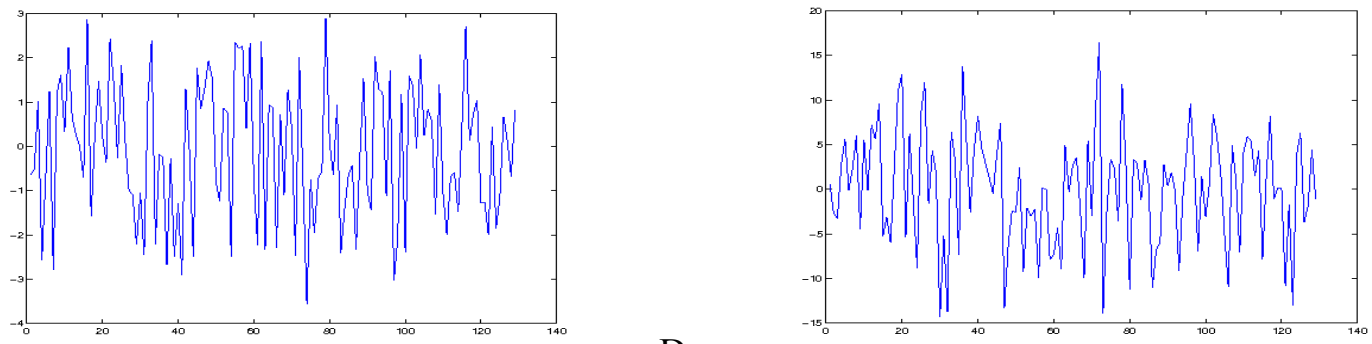

$\mathrm{D}_{3}$
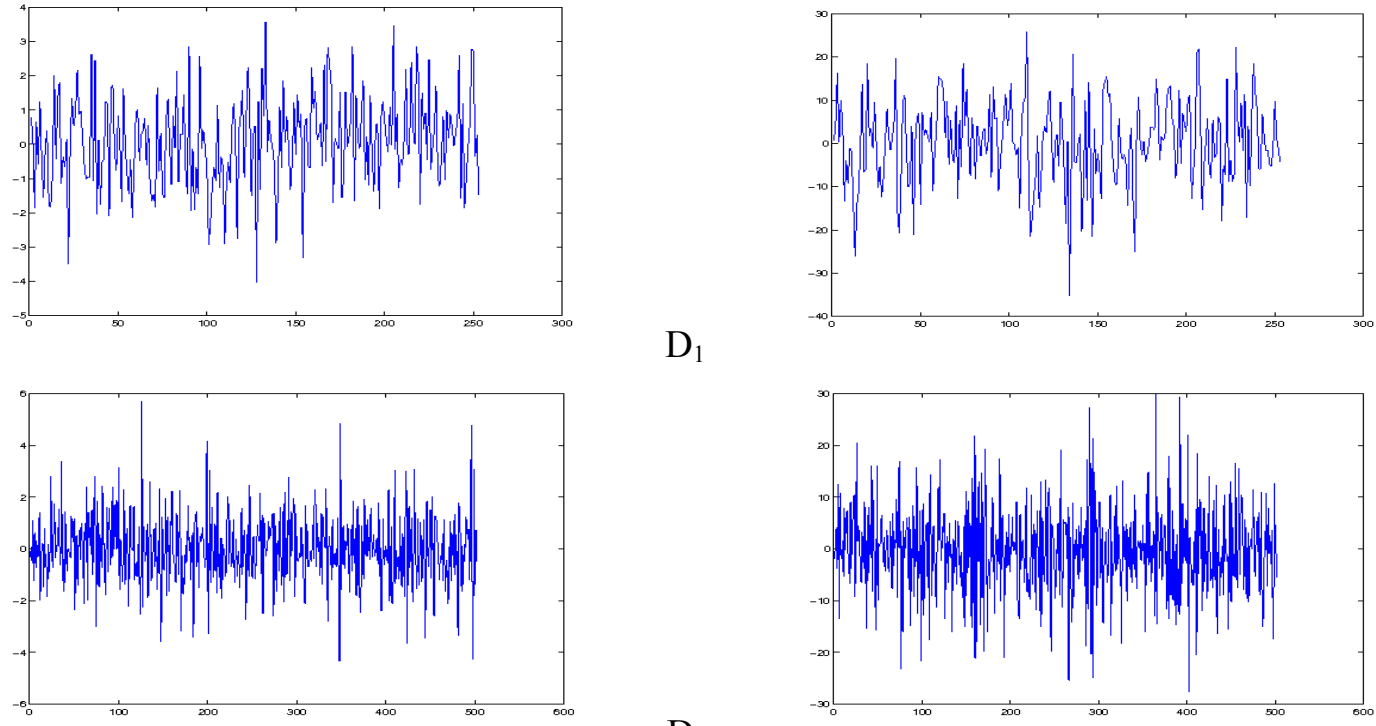

przed

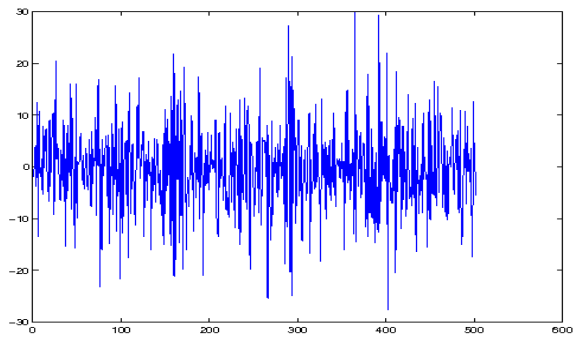

po

Rys. 5. Przykład analizy wielorozdzielczej dla 5 poziomowej dekompozycji 
częstotliwościowych pokazuje zdecydowana różnice pomiędzy sygnałami przed i po (patrz rys. 5). Należy więc ocenić, że falki nadają się do będą potrafiły wychwycić różne stany silnika na podstawie sygnałów wibroakustycznych. Równocześnie jednak należy podkreślić, że ocena wizualna wykresów czasowoczęstotliwościowych nie nadaje się do szybkiej diagnostyki on-line.

Do tego celu zastosowano analizę wielorozdzielczą. Przykład analizy wielorozdzielczej jest pokazany na rys. 3. W analizie wielorozdzielczej otrzymujemy rozkład oryginalnego sygnał na składowe aproksymacyjny na różnych poziomach szczegółowości.

Analizując wyniki dekompozycji można zauważyć podobieństwo pomiędzy wykresem oryginalnego sygnału $\mathrm{S}$ oraz wysoko częstotliwościowej składowej sygnałowej $\mathrm{D}_{1}$. Największe różnice przy porównaniu sygnałów przed i po remoncie pojawiają się (patrz rys. 5) dla kładowych sygnałowych niskoczęstotliwościowych $\mathrm{A}_{5}$ i $\mathrm{D}_{5}$. Wówczas proste parametry opisujące sygnał $\mathrm{w}$ zastosowaniu do składowych sygnałowych niskoczęstotliwościowych powinny potrafić zróżnicować stany silnika przed i po naprawie. Pierwsze wyniki dla para metrów takich jak średnia, wariancja oraz wartość połówkowa histogramu pokazują, że jest to istotnie możliwe.

\section{Wnioski końcowe}

Dotychczasowe badania w zakresie zastosowania falek do analizy własności sygnałów wibroakustycznych, które reprezentują różne stany silnika spalinowego Diesla są interesujące. Uzyskane rezultaty pokazuja, ze falki, a przede wszystkim, analiza wielorozdzielcza bazująca na falkach, może się okazać skuteczną i użyteczną metodą detekcji uszkodzeń oraz oceny stanu silnika spalinowego w transporcie kolejowym. Pierwsze badania napotkały jednak na wiele utrudnień i problemów. Jednym z takich problemów jest wybór odpowiednich rodzajów falek oraz dopasowaniu ich parametrów do konkretnej sytuacji. Nie jest to zadanie proste bowiem trudno $\mathrm{z}$ góry zadecydować jakie falki stosować. Wymaga to najczęściej przebadania wszystkich możliwych rodzajów falek, co staje się bardzo czasochłonne. Problemem jest również praktyczna diagnostyka on-line, do której nie nadaje się ocena wizualna dwuwymiarowych obrazów czasowo-częstotliwościowych. Praktyczna diagnostyka nie może opierać się na rozpoznawaniu dwuwymiarowych obrazów czasowo-częstotliwościowych. Powinna raczej oprzeć się na wyborze jednego lub kilku parametrów nadających się do szybkiej diagnostyki on-line. W tym zakresie dopiero analiza wielorozdzilecza pokazuje na nowe możliwości zastosowań diagnostycznych. Oddzielne pojedyncze parametry opisujące sygnały składowe po dekompozycji na wyższych poziomach moga zostać użyte jako parametry diagnostyczne.

\section{Literatura}

[1] Al-Badour F., Sunar M., Cheded L.: Vibration analysis of rotating machinery using time-frequency analysis and wavelet techniques. Mechanical Systems and Signal Processing, vol. 25, pp. 2083-2101, 2011.

[2] P. Boguś, J. Merkisz, R. Grzeszczyk, S. Mazurek: Nonlinear Analysis of Combustion Engine Vibroacoustic Signals for Misfire Detection. SAE Technical Paper Series 2003-010354.

[3] P. Boguś, K. Lewandowska: Short-Time Signal Analysis Using Pattern Recognition Methods. Lecture Notes in Artificial Intelligence: Artificial Intelligence and Soft Computing, 3070, 2004.

[4] P. Boguś, J. Merkisz: Diagnostyka pokładowa silników wysokopręznych $z$ wykorzystaniem nieliniowych metod analizy sygnałów. Pojazdy Szynowe, 1/2004.

[5] P. Boguś, R. Grzeszczyk, J. Merkisz: Diagnostyka pokładowa silników wysokoprężnych z wykorzystaniem chwilowej analizy sygnatów. Pojazdy Szynowe, 1/2004.

[6] P. Boguś, J. Merkisz: Wykrywanie zjawiska wypadania zaptonu $w$ silniku o zaplonie samoczynnym $w$ oparciu o grupowanie danych $w$ krótkoczasowej analizie sygnatów wibroakustycznych. Silniki Spalinowe, 4, 2005.

[7] P. Boguś, J. Merkisz: Misfire Detection of Locomotive Diesel Engine by Nonlinear Analysis. Mechanical Systems and Signal Processing, 19, 2005.

[8] P. Boguś, J. Merkisz: Short Time Analysis of Combustion Engine Vibroacoustic Signals with Using Pattern Recognition Techniques. SAE Technical Paper Series 2005-01-2529.

[9] P. Boguś, A. Sienicki, E. Wojciechowska, J. Merkisz: The comparison of vibroacoustic signals taken from an engine before and after repair. Combustion Engines, 2007-SC3.

[10] P. Boguś, A. Sienicki, E. Wojciechowska. Porównanie stanu silnika lokomotywy spalinowej ST44 przed i po remoncie przy użyciu sygnatu wibroakustycznego. Pojazdy Szynowe, 2/2007.

[11] P. Boguś, J. Merkisz, S. Mazurek. The Prospect of Artificial Intelligence Methods in Identification and Prevention of Critical Railway Accidents. In: L. Rutkowski, R. Tadeusiewicz, L. Zadeh, J. Zurada (eds.). Computational Intelligence: Methods and Applications. EXIT, Warsaw 2008, str. 445-453.

[12] P. Boguś, J. Merkisz. Zastosowanie analizy falkowej $w$ diagnostyce silnika spalinowego. Combustion Engines, 2013, 154(3), str. 226-231. ISSN 0138-0346-MniSW = 7.

[13] K. Chui K.: Wavelets: A Mathematical Tool for Signal Processing. SIAM Society for Industrial and Applied Mathematics, 1997.

[14] Goswami J. C., Chan A. K.: Fundamentals of Wavelets. Theory, Algorithms, and Applications. John Wiley \& Sons, Inc., 2010.

[15] Madej H.: Metody przetwarzania sygnatów wibroakustycznych $w$ diagnozowaniu silników spalinowych. Zeszyty Naukowe Politechniki Ślaskiej, Seria: Transport, z. 69, pp. 97-104, 2010.

[16] P. Mening, C. Coverdill: Transportation Recorders on Commercial Vehicles. International Symposium on Transportation Recorders, Arlington, Virginia, 1999.

[17] J. Merkisz, S. Mazurek: Pokładowe systemy diagnostyczne pojazdów samochodowych. Wydawnictwa Komunikacji $i$ Eaczności, Warszawa, 2002.

[18] Tsea P. W., Yangb W., Tama H. Y.: Machine fault diagnosis through an effective exact wavelet analysis. Journal of Sound and Vibration, vol. 277, pp. 1005-1024, 2004.

[19] J. R. Wootton, A. Garcia-Ortiz: Intelligent Transportation Systems: A Global Perspective. Mathl. Comput. Modellin, 22, 1985.

[20] G. T. Zheng, A. Y. T. Leung. Internal Combustion Engine Noise Analysis With Time-Frequency Distribution. Journal of Engineering for Gas Turbines and Power, JULY 2002, Vol. 124, pp. 645-649 